Comunicação e Sociedade, vol. 7, 2005, pp. 49-67.

\title{
From the myth of cyberspace to the political economy of computer communication
}

Vincent Mosco*

\begin{abstract}
The development of computer communication in the 1980s and 90s gave a new impetus to the set of myths connecting information technologies to the end of space, the end of time, the end of politcs and the end of history. Based on the Political Economy perspective, this article challenges the foundations of this symbolic construct and explains its unsustainability. Along these lines, it will be argued that cyberspace results from the mutual constitution of digitalization and commodification. Due to its potential to combine universial language with customized products, digitalization expands the commodification of content by expanding opportunities to measure and monitor, package and repackage entertainment and information. Mythic cyberspace might therefore might be little more than an highly commercialized space with scarce room for diversity and debate.
\end{abstract}

Key words: political economy, myth, cyberspace, digitalization, commodification

In the 1980s and 90s, with the arrival of global computer communication, the vision of a post-industrial society broadened into a set of myths connecting information technologies and the Internet to the end of history, the end of geography, and the end of politics. Myths can be understood for what they reveal, for example, the desire for identity and community, but also for what they conceal. In this case the myths of cyberspace are primary examples of what Roland Barthes (1972) meant when he defined myth as depoliticized speech. But they can also open the way to a renewed politics, particularly when the cultural analysis of myths is connected to political economy.

\footnotetext{
* Detentor da Canada Research Chair in Communication and Society, Universidade de Queens (Canadá) e ex-Presidente da
} Secção de Economia Política da International Association for Media and Communication Research (moscov@mac.com) 
Myths conceal a great deal about the politics of cyberspace and in order to appreciate the significance of this point, it is useful to turn to the political economic relationship between digitization and commodification. They are central points on the bridge between the culture and the political economy of cyberspace. These two processes provided the foundation for the technological sublime that grew out of "magic places" like California's Silicon Valley and New York City's Silicon Alley and the grounding for the belief that we are entering the end of history, geography, and politics.

Digitization refers to the transformation of communication, including words, images, motion pictures, and sounds into a common language. Providing the grist for cyberspace, it offers enormous gains in speed and flexibility over earlier forms of electronic communication which were largely based on analog techniques (Longstaff, 2002). The latter physically mimicked communication by putting it into a form suitable for electronic processing and transmission. For example, on an analog system, the voice of a telephone caller creates a series of vibrations whose characteristics are sent over a wire and, provided they are amplified at regular intervals, transmitted to a receiver. A digital system literally translates that voice signal into the familiar code of ones and zero's which have become the common language of electronic communication. Rather than the multiplicity of mechanical analogues that were employed to process oral, verbal and image signals, digitization enables one language to govern practically all electronic media. The fundamentals of translating, processing and distributing electronic communication no longer distinguish among a page of newspaper copy, a radio news broadcast, a CD recording, a telephone call, a television situation comedy, and an e-mail message. Each can be sent at high speed over various wired and wireless networks.

Adopting a common, universal language for electronic media makes digitization enormously attractive. But another characteristic produces an additional significant leap in efficiency and flexibility. Digitization processes and distributes signals in packets that vary in size depending on the nature of the network. A digital telephone network does not send out an entire voice message, as did the old analog systems, but rather packages the message in groups for transmission. Each group or packet is provided with a discreet digital address which identifies it before transmission. Breaking up telephone calls, or television signals for that matter, into identifiable packets enables them to be shipped over different network routes on their way to reunification at the receiving end. In effect, one piece of a telephone signal may be followed by a piece of a television signal, with another piece of that same telephone call sent over another network. This provides significant gains in the efficiency of communication networks which used to become congested with traffic that could not be rerouted easily or broken up for efficient transmission. Communication is also made more effective because redundancy can be built into messages enabling multiple ways to correct for errors at the processing and distribution stages. Varieties of what is called "packet switching" thereby combine the universalizing tendencies of digitization with intelligent customization of communication packets to greatly expand the efficiency and effectiveness 
of electronic communication. Viewed in this way, digitization combines elements of generalization, by applying one process or one language to electronic communication, with customization, by packaging its "inventory" of communication into micro units that produce the most efficient flow through networks. Myth-makers jump from here to the view that the world of atoms is morphing into a virtual utopia and it sometimes leads urban planners to confidently remake entire regions - with destruction and dislocation considered a small price to pay for what amounts to an inevitable and necessary transformation in social life.

Digitization takes place along with the process of commodification or the transformation of use to exchange or market value. The expansion of the commodity form provides what amounts to the material embodiment for digitization. It is used first and foremost to expand the commodification of information and entertainment content, enlarge markets in the audiences that take in and make use of digitized communication, and deepen the commodification of labor involved in the production, distribution and exchange of communication. Digitization works in the context of powerful commercial forces and also serves to advance the overall process of commodification worldwide. In other words, commercial forces deepen and extend the process of digitization because it enables them to expand the commodity form in communication. From a cultural or mythic perspective, cyberspace may be seen as the end of history, geography and politics. But from a political economy perspective, cyberspace results from the mutual constitution of digitization and commodification.

Digitization expands the commodification of content by extending opportunities to measure and monitor, package and repackage entertainment and information. The packaging of material in the paper and ink form of a newspaper or book has provided a flexible, if limited, means to commodify communication by offering a useful form in which to measure the commodity and monitor purchases. Challenges arose when what Bernard Miège calls "flow" type communication systems arose, most significantly, television (Miège, 1989). It forced the question: how does one package a television program for sale to a viewer? Initially, commodification was based on a relatively inflexible system of delivering a batch of channels into the home and having viewers pay for the receiver and for a markup on products advertised over the air. This system did not account for different use of the medium; nor did it make any clear connection between viewing and purchasing. It amounted to a "fordist" system of delivering general programming to a mass audience which was marketed to advertisers for a price per thousand viewers. Each step along the way to the digitization of television has refined the commodification of content, allowing for the flow to be "captured" or, more precisely, for the commodity to be measured, monitored and packaged in increasingly more specific and customized ways. Early cable television improved on commodification by charging per month for a set of channels. As this medium has become digitized, companies now offer many more channels and package them in multiply different ways, including selling content on a pay-per view basis. Material delivered over television, the Internet or some combination of these and other new wired and wireless 
systems can now be packaged and repackaged for sale in some related form with the transaction itself measured and monitored by the same digital system. There are certainly limitations on this process. People have been leaving newspapers in cafés, sharing books, and otherwise confounding the precision of the commodification process for as long as the mass media have been around. So it comes as no surprise that music file sharing has become a way to avoid the high price of a music CD. But companies now have tools available to fight back with the support of governments more intent than ever to enforce media ownership rights and with technologies that increasingly provide what is being called the "digital armor" that significantly constrains the capacity to copy and share digital media. The process of commodifying media, along with the back and forth which defines its extent and limitations, describes something far more banal than the end of history, but there is considerable power in this banality.

Enhancing this power, the recursive nature of digital systems expands the commodification of the entire communication process. Digital systems which measure and monitor precisely each information transaction can be used to refine the process of delivering audiences of viewers, listeners, readers, movie fans, telephone and computer users, to advertisers. Companies can package and repackage customers in forms that specifically reflect both their actual purchases and their demographic characteristics. These packages, for example, of 18-25 year old women who order pop music concerts on pay-per view television, can be sold to companies, which spend more for this information because they want to market their products to this specific sector with as little advertising wasted on groups not interested or able to buy. This refines the commodification of viewers over the fordist system of delivering mass audiences to advertisers and it is being applied to almost every communication medium today. The applications are not always successful, as almost anyone trying to market the Internet version of early radio's "University of the Air" will attest. Applications often meet with more than a little resistance because they are too demanding (program my VCR? interact with my TV set?) or too intrusive (why do you really need to know my age and income?) or simply don't do what they are supposed to (you call that jumpy little picture on my desktop a video?) Nevertheless, there is also great power, even if not that of sublime mythology, in the commodification of audiences.

The labor of communication is also being commodified as wage labor has grown in significance throughout the media workplace. In order to cut the labor bill and expand revenue, managers replaced mechanical with electronic systems to eliminate thousands of jobs in the printing industry as electronic typesetting did away with the jobs of linotype operators. Today's digital systems allow companies to expand this process. Print reporters increasingly serve in the combined roles of editor and page producer. They not only report on a story, they also put it into a form for transmission to the printed, and increasingly, electronic page. Companies generally retain the rights to the multiplicity of repackaged forms and thereby profit from each use. Broadcast journalists carry cameras and edit tape for delivery over television or computer networks. The film industry is now starting to deliver digital copies of movies to theaters 
in multiple locations over communication satellite, thereby eliminating distribution of celluloid copies for exhibition by projectionists. Rather than break down Hollywood's rigidly concentrated power structure, as some forecast, ${ }^{1}$ digitization and commodification strengthen it. Companies sell software well before it has been debugged on the understanding that customers will report errors, download and install updates, and figure out how to work around problems. This ability to eliminate labor, combine it to perform multiple tasks, and shift labor to unpaid consumers further expands the revenue potential (Hardt and Brennen 1995; McKercher, 2002; Sussman and Lent, 1998). Workers have responded to this with their own form of convergence, one that brings together people from different media, including journalists, broadcast professionals, technical specialists in the film, video, telecommunications and computer services sectors, into trade unions that represent large segments of the communications workforce. The goal of one big union in cyberspace may be a mythical ideal but there is no doubting the trend toward labor and trade union convergence in the communication industries (McKercher, 2002; Mosco, 2002).

\section{Corporate integration and concentration}

The mutual constitution of digitization and commodification contributes to the integration of the communication and information technology sector and the concentration of corporate power within it. The adoption of a common digital language across the industry is breaking down barriers that separated print, broadcasting, telecommunications and the information technology or computer data sectors. These divisions have been historically important because they contained the legal and institutional marks of the particular period in which they rose to prominence. The print publishing industry is marked by a legal regime of free expression, limited government involvement, and local ownership.

Broadcasting and telecommunications rose to prominence alongside the rise of powerful nation-state authority and national production, distribution and exhibition systems. Western legal systems placed a greater regulatory burden on radio, television, and telephone systems, going as far as to create publicly controlled institutions in these sectors, in order to accomplish national objectives such as reflecting a national identity and building a national market. National firms were more likely than their more local print predecessors to control commercial broadcasting and telecommunications systems. The information technology or computer data industry took off in the postWorld War II era and embodies the trend away from nation-state regulation, except to advance the expansion of businesses, and toward control by multinational firms. There are numerous legal and institutional struggles within this sector, but it arguably

\footnotetext{
${ }^{1}$ As one analyst put it, "when digital filmmaking's full potential is reached, a growing number of people in the industry believe, it might even threaten a studio power structure that has held firm since the advent of sound and has absorbed such technological challenges as television and VCRs." (Lyman, 1999)
} 
began from the premise that, unlike the broadcasting and telecommunications sectors, the computer industry would face little or no public interest or public service responsibilities, no subsidized pricing, no commitment to universality of access, and no expectation that national firms would be anything more than one step on the way to multinational control (Schiller, 1999; McChesney, 1999). This has become the model for the convergent communication industry.

The growing integration of communication sectors into a consolidated electronic information and entertainment arena explains much of why there has been an unprecedented acceleration in mergers and acquisitions. Communication systems in the U. S. are now largely shaped by a handful of companies including U. S. -based firms: Microsoft, AT\&T, General Electric, Viacom, Inc., the Walt Disney Company, Time Warner, and the Liberty Media Corporation. There are others, including non-USbased firms like News Corporation, Bertelsmann, Vivendi Universal, and Sony. Each of these firms also has a significant transnational presence through outright ownership, strategic partnerships, and investment.

Concentration is far from just an American phenomenon. Consider Canada whose communication arena is arguably even more highly concentrated with four firms in the most dominant positions. These include BCE, Rogers Communication, CanWest, and Quebecor. (Some might add a fifth firm, Shaw Communication). BCE alone has spread over a wider terrain than even its admittedly larger American and European counterparts. The company's former chair and CEO boasts about what would be the U. S. equivalent of BCE: "Start by combining the telephone businesses of Verizon Communications and SBC Communications. Then add Verizon's wireless operations, and America Online's Internet customers. Fold in ABC's television network, the ESPN cable sports network and the Direct-TV satellite service. Finally, tack on The New York Times." (Simon, 2001) Marveling at Bell's ability to dominate the Canadian industry, a correspondent concludes that American antitrust officials and regulators would not permit such a conglomerate to be assembled in the U. S. (Ibid.). Whether this is true is debatable, but the combination of growing concentration and diminishing regulation certainly leads some, such as Cass Sunstein (2001), to fear that cyberspace will shrink from its mythic potential to advance democracy and become little more than a commercial space with less than adequate room for diversity and the clash of ideas.

The transformation, however, is far from complete. Canadian communication firms, like their counterparts in the United States, Europe and elsewhere face enormous pressures toward regional and global integration (Mosco and Schiller, 2001). In order to advance transnational corporate communications services in general, and communication services in particular, nationally controlled institutions would have to be eliminated or at least marginalized, and public service principles would have to be sharply reduced. U. S. corporate and political leaders lobbied intensively during the 1980 s and 1990s to advance these changes within broader efforts to liberalize trade and investment rules. Playing important roles in this process were government initiatives, private economic diplomacy, bilateral negotiations between states, and multilateral 
organizations such as the World Bank, the International Monetary Fund, the World Trade Organization. The Free Trade Agreement (FTA) which brought together Canada and the United States and the North American Free Trade Agreement (NAFTA), which added Mexico, made up significant initiatives within this larger movement. Each was perceived as a prelude to a broader push for liberalization of global trade and investment within the organizational context of the frameworks established by the General Agreement on Tariffs and Trade (GATT) and the World Trade Organization (WTO).

\section{Tensions and contradictions}

Media concentration is a powerful force, but, as the dot-com and telecommunications debacles reveal, it often does not produce the synergies that companies anticipate and sometimes results in content that does not succeed in attracting audiences. Focusing as it typically does on the corrosive consequences of media integration, political economy tends to give inadequate attention to this point. At worst, the presumed power of media giants takes on its own mythic characteristics. Digitization is not a flawless process and technical problems have slowed its development. Furthermore, we can observe significant political contradictions. Arguably the dominant political tendency today is neoliberalism which was founded on the retreat of the state from vital areas of social life, including communication, where the state was once very significantly involved in building infrastructure, establishing technical standards, regulating market access, and providing services. According to neo-liberalism, such functions are best provided by the private sector with minimal state involvement. Specifically, neo-liberalism aims to customize state functions, tailor them to suit business needs, and thereby avoid what its supporters contend is the stalemate created by excessive public demands for state services.

The communication arena demonstrates that it is not so easy to accomplish this feat. Consider first the development of technical standards. Digitization needs common technical standards to harmonize the processing, distribution, and reception of digital signals. It is one thing to turn audio, video, and data streams into digital packets; quite another to ensure their flawless flow through global grids. To accomplish this, it is essential to set a wide range of standards for the equipment necessary to encode and decode signals and for managing data flows through networks. Achieving such agreement is normally quite difficult since competing firms are reluctant to cooperate because it requires sharing sensitive and economically valuable information. Societies have traditionally dealt with this problem by establishing government agencies or private-public partnerships to serve as independent standards arbiters. Almost a century and a half ago, competing telegraph interests established the International Telecommunications Union (ITU), a global body comprised of mainly government organizations and managed on a one-nation, one-vote basis to set global standards for the new technology. Over the years, the ITU expanded its role as each new communication technology came along. Primarily, it set standards for the telephone, allocated broadcasting frequencies, and eventually the orbital locations of communication satellites. 
However, as the number of nations grew, including former colonial societies eager to create standards that would help them to expand widespread access to communication technology (and not just the profits of communication companies), conflict grew at the ITU. As a result, core industrial powers, led by the United States, began to consider alternatives. These included, first, political bodies, like Intelsat, a global communication satellite organization whose rules permitted Western control and more recently, private corporations, such as ICANN, the Internet Corporation for Assigned Names and Numbers, which helps to establish technical standards for the Web. The goal of these organizations has generally been to set business-friendly standards, but to do so without sacrificing global credibility.

The problem for defenders of this system is that it is increasingly difficult maintain both business support and global credibility. One reason is that digitization is now global and the competition to dominate markets for the short term by controlling one phase of a rapidly changing system or for the long term by setting an important standard (such as for a computer operating system) is intensifying (Paré, 2003). Furthermore, the number of global interests is expanding so that even something as seemingly innocuous as setting a national suffix for a web address becomes a political question when, to cite one particularly fractious case, it is Palestine petitioning for . ps (Clausing, 1999). Should the common ".com" suffix expand to include ".union" as one public interest group proposed? Private businesses expect to depoliticize these issues by setting up Western controlled private or only quasi-public standards organizations. But they are actually only displacing tensions and contradictions.

In 2002 ICANN ultimately succeeded in eliminating democratically elected members of its board, but even this neo-liberal stroke does not guarantee smooth functioning (Jesdanum, 2002). The decision got rid of elected board members like Ken Auerbach who tried to democratize ICANN but consistently ran up again major bureaucratic and political problems. In frustration about trying to obtain ICANN financial records, he once complained that "We know more about how the College of Cardinals in Rome elects a pope than we do about how ICANN makes its decisions." (Associated Press, 2001a) Auerbach met ICANN executives' refusal to provide him with the organization's records by turning to a judge who supported the dissident director's request. ICANN responded by eliminating Auerbach and other elected board members (Geist, 2002a). One telecommunications analyst now calls for the elimination of ICANN, charging that the agency sunk to a new low by meeting in locations distant from most of the activists who have been pressing for change in order to keep them from showing up at meetings. The decision to eliminate elected board members was made at an ICANN meeting in Shanghai, China, hardly a bastion of democratic communication. Critics contended that it was also a site that would press the budgets of ICANN's dissidents (Weinstein, 2002). They wonder about the irony of an international organization set up to address the needs of the new online global community, appearing to do what it can to keep its representatives as far away as possible. Returning to the world of myth, one is tempted to wonder, perhaps with tongue in cheek, if this is what the "end of geography" really means. 
In light of the numerous disputes, often very acrimonious, one should therefore not be surprised that ICANN's legitimacy has suffered. Moreover, it should come as no surprise to learn that savvy computer users are, to use geek lingo, developing "work arounds" for the ICANN problem. A 2001 report found more than 500 top-level domains operated around the world by some 200 administrators, all outside the official domain name system (Weiss, 2001). How many more rogue networks will be added to that total as ICANN loses more of its legitimacy? One seemingly ironic consequence has been a stepped-up effort to shift international decision making power over domain names to the grand old regulatory body, the ITU, which in October 2002 approved a resolution on managing multilingual domain names and one analyst has gone as far as to suggest that the ITU will likely emerge "as the governance leader.” (Geist, 2002b) Many participants at the 2003 World Summit on the Information Society pushed hard for transferring power from ICANN to the ITU. Nevertheless, this alternative, setting up genuinely public, national or international regulatory authorities, a central feature in the expansion of communication before post-industrialism became the reigning myth, risks turning this arena into a highly contested terrain.

The contradiction between the desire to free business to act in its own interest and the need for government regulation has also marked debates about how to expand access to technology in order to build markets and about how to ensure some measure of privacy to create consumer confidence in the technology. For example, in the early days of radio, business felt that it did not need government to regulate frequencies (after all, this was the end of history). But the result was near chaos, as broadcasters poached each other's frequencies and the airwaves were filled with worthless static. Businesses responded by supporting government regulation which succeeded in bringing some order to the chaos. However, this private arena was now opened to the wider public which used the opportunity to fight for public broadcasting and the regulation of private station content. The technology has indeed changed, leading some to reimagine revolutionary transformations, but the political economic dynamic has not and so the same tensions and contradictions mark the world of digitization.

Consider the shocking burst of the telecommunications bubble. Once industry giants like Nortel, Cisco, Lucent, and now WorldCom (this icon of the telecom boom was bounced from the Nasdaq and S\&P 500 in 2002 and had its credit rating reduced to junk status), shrink into economic obscurity. Between 2000 and 2002, Nortel and Lucent lost 98 percent of their stock value and, between the two alone, shed 148,000 jobs out of a total of more than 500,000 lost in the U. S. telecommunications industry. WorldCom's demise is extraordinary even in the context of the most substantial crash in the history of the telecommunications industry. Once America's second largest telecommunications carrier, the company filed for bankruptcy in July 2002. With \$107 billion in assets, it was the largest such action in United States history. By October 2002 the company had been charged with $\$ 7.4$ billion worth of accounting irregularities. Building its capitalization on a variety of shady practices, including its proclamation that Internet traffic was doubling every 100 days, a claim dignified in government re- 
ports that repeated it, WorldCom appeared to be the new model for the Internet-savvy telecommunications industry. Aided by the Telecommunications Act of 1996, which diminished scrutiny over the company, WorldCom enjoyed what amounted to a blank check from regulatory authorities. By March 2003 the company had to write down its assets by $\$ 80$ billion, including lowering the value of its tangible assets from the $\$ 44.8$ billion paid down to $\$ 10$ billion. This led one industry analysis to conclude "So Worldcom paid \$1 for assets that are now worth 2 cents. At last we know how gross was the misallocation of capital in the telecommunication industry in the late 90's. And how deep is the telechasm." (Morgenson, 2003) Or as a former deputy general counsel at the FCC put it, "the agency was oblivious to the enormous accounting fraud at WorldCom." He called for stripping the company of the licenses and certifications it needs to do business (Sidak, 2002: A31). But WorldCom, though arguably the worst case, was hardly alone. At the end of 2001, the eight largest telecommunications companies collectively owed $\$ 191$ billion and, with demand flat, there was little prospect of debt repayment (Goodman, 2002). This was partly because even companies like AT\&T and Sprint, which have not been accused of WorldCom's offenses, faced enormous pressure to meet the quarterly results that WorldCom appeared to be generating. Unable to do so legitimately, they saw their stock value pummeled, and even these companies were forced to restructure operations and replace senior management (Schiesel, 2002).

Beneath these sobering facts lie what some fear is a fundamental change in the nature of research in these vital industries. The most telling example is the case of $\mathrm{J}$. Hendrik Schon who worked for Lucent Technologies' Bell Labs. The microelectronics community was rocked in 2002 when an expert panel determined that Schon, who had risen to the mythic status of science superstar for his work on molecular-level transistors, determined that he fabricated data and altered experimental results for work published in the field's most prestigious journals including eight in the journal Science. Under intense corporate pressure to produce breakthroughs in nanotechnology, Schon and some of his colleagues cheated. The views of theoretical physicist and MacArthur "genius" grant winner Paul Ginsparg are telling. In response to a question about what the Schon case means, he did not hesitate: “The demise of Bell Labs by becoming corporate. People just assumed that there's no way that institution would allow this to happen. And let me tell you, years ago this never would have happened at Bell Labs. The heads of departments would have kept tables. The investigating committee asked Schon, Where are your lab notebooks, and he didn't systematically keep them. Raw data? Didn't keep them." (Weed, 2002: 27) Fearing the loss of some of America's fundamental communication equipment providers, the chairman of the Federal Communications Communication actually resorted to a speech pleading with the telephone companies and other telecommunications operators to buy more equipment. To which the chief procurement executive for Verizon, a major telecommunication operator in the United States which continues to cut back on its own workforce responded, "we're not to the point where we are going to reach in and send a check to support them. That's not going to happen.” (Feder, 2002) 
The overall decline in the dot-com and telecommunications industries, and, most importantly, the chasm between the massive glut of high-speed, long haul information lines and the shortage of high-speed, local access connections, can be directly traced to the almost religiously driven neo-liberal strategy that the market would do a better job of regulation than traditional forms of state intervention. Indeed, cyberspace fed a powerfully compelling myth of the market that insisted we have reached a point where policy can do away with government regulation. Friction-free capitalism, as Bill Gates called it, was at hand and Washington would take the lead by eliminating many of its own responsibilities. So with few regulatory, political or social policy checks on investment decisions, cemented into law in various forms, in the U. S. it was the 1996 Telecommunications Act, firms went on a long haul building binge. Once the Bush Administration came to power in 2001, key regulatory agencies like the Securities and Exchange Commission and the Federal Communications Commission weakened regulatory oversight and enforcement even more. The building binge was carried out by large as well as small firms. Assets mattered little because Wall Street was flush with "new economy fever" (after all this was the end of history) and capital was easy to raise.

Even liberals bought into this view with their own mythology: If you build it, they will come. Well, as it turns out, to summarize a government report of September 2002, despite the fact that almost all U. S. families live in areas where a high-speed Internet connection is available, many see no compelling reason to pay extra for it (U. S. government, Department of Commerce, 2002). People who once envisioned the "broadband revolution" now predict a slow evolution with declining annual growth rates resulting in, at best, one-third of U. S. households with broadband by 2006 (Romero, 2002b). Similar results documenting the persistence of cyberspace "choose-nots" have been found in Canada (Reddick, 2002). Some have even come to doubt the economic value of combatting the "digital divide" between rich and poor nations (Kenny, 2003). This has not stopped people from trotting out version after version of the myth. According to one technology reporter, "Perhaps it is time to update the old adage: 'If you give me a fish, you feed me for a day. If you teach me to fish you feed me for life.' Maybe it should now say: 'If you give me information, you answer one of my questions. If you get me online, you let me answer my questions for myself'." (Thompson, 2002) Even a report from a left-wing think tank, published in the midst of the most substantial decline ever experienced by the telecommunications industry, calls for diminishing regulation of telephone companies (referred to as "regulatory symmetry") to enable them to speed up the production of broadband networks (Pociask, 2002). Nevertheless, by the end of 2002 it remained the case that, aside from eBay, which also has it doubters on Wall Street, and, to an even lesser degree, Amazon, the only businesses actually making money from the Web were, as one article gingerly put it, those "appealing to baser interests or making use of questionable business practices." Among these were sex-related businesses including subscriptions to image and video sites and businesses promising enhanced sexual prowess (Schwartz, 2002a; Tedeschi, 2002). 
Caught in the crunch, industry leaders are not particularly optimistic. As one from AT\&T put it, "I think that approach of 'build it and they will come' has been a disaster for the industry. I don't think we're ever going to see it again.” (Howe, 2002) Not everyone agrees with this point of view. Michael Lewis, author of The New New Thing, a best-seller praising the Internet, writes "In Defense of the Boom," that it was far better than the current wave of "retribution" would admit. Sure, companies overbuilt the telecommunication system adding unnecessary capacity, "which is a bit wasteful - we don't need it yet - but not a total waste: we will need it one day soon." (Lewis, 2002: 49)

One company that persists in this view is Global Crossing which was once touted by Internet myth-maker George Gilder to be a solid contender to dominate the telecommunications industry in the new century. This firm, led by a protégé of junk bond felon Michael Milken, managed to raise $\$ 750$ million almost overnight, went public, reached a value of $\$ 30$ billion, built a transatlantic fiber network valued at much less and with a glut in capacity (actually 95 per cent of fiber network capacity goes unused) collapsed in January 2002. The company's share value declined by 99 percent to 13.5 cents a share and it filed for bankruptcy in January 2001, the largest one by a telecommunications company, joining other high fliers like 360 networks, which Gilder, in another one of his influential prognostications, claimed would battle Global Crossing for telecommunications supremacy in the twenty-first century (Romero, 2002a; "The Great Telecoms Crash," 2002). Fearing a case of "Enronitis," the F. B. I and the Securities and Exchange Commission launched investigations of the company in February 2002. As it turns out, Global Crossing was literally connected to the icon of corporate malfeasance Enron in a complex deal brokered by a third party which enabled both Enron and Global Crossing to circumvent accounting rules, allow both firms to book revenue, and Global Crossing to hide a loan (Barboza and Romero, 2002: C5). ${ }^{2}$ This appears to be part of a wider practice whereby Enron and other energy companies sought to demonstrate that they were comers in the broadband communication business by trading broadband capacity back and forth with one another, thereby pumping up the appearance of major activity in the broadband market (Barboza, 2002: C1). These firms were the real magicians of the marketplace, confounding the known laws of economics and physics by making something appear from nothing and making their top executives very wealthy in the process.

Comparing the telecom situation to Enron, one business correspondent concluded in March 2002 that "a tragedy of identical plot, but with far more damaging implications," is playing out in telecommunications. However, unlike the saga of Enron, this is not about a single company with mischievous executives, "this tale is about

\footnotetext{
${ }^{2}$ Enron was not the only friend of the Bush Administration with ties to Global Crossing. In 2003 the company agreed to pay Richard N. Perle, a close Bush adviser and chairman of the influential Defense Policy Board, $\$ 725,000$ to help the company win government approval to sell the company to a joint venture based on Hong Kong and Singapore. His support was considered particularly important since both the Pentagon and the FBI opposed the sale (Labaton, 2003).
} 
an entire industry that rose to a value of $\$ 2$ trillion based on dubious promises by Wall Street and company executives for an explosive growth in demand." Cozy relations among formally competing firms led to what seems to be agreements to pad demand forecasts, overvalue assets and otherwise cook the books (Morgenson, 2002: 1). Insiders were able to dump their stock at inflated prices before the collapse set in (Berman, 2002). As, according one article, "the fiber optic fantasy slips away," the promise of universal access to broadband communication remains just a promise (Romero and Schiesel, 2002).

Meanwhile, in another spin of the wheel, even well known bankers like Felix Rohatyn, who once engineered a bailout when New York City declared bankruptcy, calls for a return to rigorous regulation to combat what he has called "the betrayal of capitalism." (Rohatyn, 2002a: 6) According to this pillar of the Establishment, "I believe that market capitalism is the best economic system ever invented for the creation of wealth; but it must be fair, it must be regulated, and it must be ethical. The excesses of the last few years show how the system has failed in all three respects... . the system cannot stand much more abuse of the type we have witnessed." (Rohatyn, 2002b: 6) The telecommunications industry has arguably suffered more than the computer industry from mismanagement and corporate crime. But Silicon Valley shows little evidence of learning from the sorry example of telecommunications. The General Counsel for a large California investment company concludes that "Silicon Valley 'corporate governance' is an oxymoron." Success is measured by money raised, newspaper mentions, and general visibility, not by revenue. According to its critics, the Valley's swashbuckling approach to management "means more shareholder disasters waiting to happen." (Richtel, 2002) ) $^{3}$ Nor does Washington hold out much hope for Rohatyn. In August 2002 President Bush reaffirmed his longstanding view that more deregulation is needed to expand access to broadband and other high-speed Internet services (Krebs, 2002). The man he appointed to head the Federal Communications Commission agreed and proceeded to launch a series of steps to further reduce restrictions on corporate activity in the mass media and telecommunications. But there are some within the industry who worry about this strategy. According to the general counsel for AT\&T, the industry's problems can be directly traced to the fact that "enforcement has not been vigorous enough. When so many problems have been a result of a lack of oversight, it's not generally wise to say let's deregulate further." (Labaton, 2002: C8) But with the Republicans winning control of the U. S. Senate in November 2002 and the Federal Communications Commission insisting that its policies are sound, deregulation, and the problems that Rohatyn has so clearly identified, continued.

\footnotetext{
${ }^{3}$ Here is how one long-time technology executive described her experience with the boards of dot-com firms: "I got off a couple of boards where I couldn't stomach what was going on. The capacity for illusion was limitless. You'd have a board meeting, and you'd say 'Where's the revenue page?' And the C. F. O. would say: 'Oh, don't worry about revenues. We're just looking at expenses, so we know when we need to raise more money.” (Race, 2002: C3)
} 
Finally, a similar conundrum shapes the issue of privacy. The drive to use communication and especially the new media of cyberspace to expand the commodification process now includes personal identity (Lyon, 2001). From a political economy perspective the threat to privacy is not just an offshoot of technology or a correctable oversight but is arguably intrinsic to the commodification process. From this point of view, the struggle for personal privacy is part of a wider one against the expanding commodity. The terrain for the struggle extends widely but "personal content" software provides one of the better examples. In January 2001 Nortel Networks announced a new line of this software that the company proposed to sell to Internet service providers. It would package online services to suit individual preferences by tracking every choice a user makes on the Internet and configure the network to deliver efficiently the kinds of material typically selected. In effect, Nortel's strategy, like that of numerous other firms, is to add value to the Internet by making it more responsive to customer profiles. But in doing so, the company makes it possible to gather, package, and share information on customer choices, thereby expanding the commodification of content and audiences. The response of one privacy activist focuses on the company's responsibility charging that it is "unacceptable" to enable Internet service providers to watch where customers are going. However, Nortel's behavior is less a matter of corporate irresponsibility and more that of a firm which needs to expand the commodification of its major resource, the Internet. Given the company's precarious financial position, it is certainly understandable that Nortel would try to build a market in expanded Internet content and in the audiences that use it. But Nortel's product also reflects a fundamental contradiction besetting the business of cyberspace, i. e., the conflict between the goals of building consumer confidence to turn the Internet and its users into a universal market and commodifying without government intervention whatever moves over the Internet, including personal identity (Associated Press, 2001b).

\section{The end of the end of history?}

In her award winning book No Logo, Naomi Klein (2000) maintains that the culture of globalization is built on the creation of a branded world. Starting from the view that the brand is "the core meaning of the modern corporation," she documents the global spread of brand identities made most successful in such visual brand icons as the Golden Arches of McDonalds and the Nike Swoosh. Brands have spread beyond the specific commercial product, like the hamburger or the running shoe, to encompass places, events, people, activities, and now governments. As Peter van Ham reminds us in a provocative piece on the postmodern or branded state, England has become Cool Britannia, tiny Belgium, reeling from scandals ranging from child pornography rings and dioxin-polluted chicken, hired a branding team that recommends the country use ". be" as its logo and follow the lead of the Virgin corporation, which isn't big but you see it wherever you look. Similarly, Estonia is no longer a post-Soviet or even a Baltic state; it is pre-EU or downright Scandinavian. Unable to boast Finland's cell phone gi- 
ant which leads some to call that country Nokialand, Estonia markets itself as a tiny green jewel, the un-Cola of industrial states and as E-Stonia, for its use of the Internet and strong presence in cyberspace (van Ham, 2001).

If we can brand countries, why not the world? Indeed, from a cultural perspective, globalization might be better viewed as a brand for the world. It exists sui generis as the word for what is happening today, not unlike the mantra whose utterance places the chanter among a group of believers who need say no more. Concepts lead to questions. As a mythic brand, globalization leads only to one response: Amen. In essence, brands are the depoliticized speech, the period, exclamation point, and cultural or rhetorical stop sign of globalization. ${ }^{4}$

But proponents of a branded world are facing global social movements that in many old and new ways resist the power of the corporate and government brand. This demonstrates that mythic brands are more than depoliticized speech. Yes, for some, the Golden Arches and the Swoosh serve as powerful stop signs to political conversation and action. But, following Doniger's position, they can also be prepolitical, the first step in a process that can restore, rather than deny, with every critical retelling, a political grounding that myths appear to leave out (Doniger, 1998). In essence, myths can end politics, can serve to depoliticize speech, but they can also restore it by providing a rich cultural dimension that deepens political understanding. Indeed, cyberspace advances a form of political convergence that makes increasingly transparent the divisions between culture and political economy as well as between consumption and labor. In doing so, cyberspace fosters an anti-globalization movement that merges the politics of labor from an earlier era (Denning, 1996) with the politics of representation that marked a more recent time (Klein, 2000). Mass demonstrations in Seattle, Prague, Quebec, Genoa, Washington, D. C., and Miami, as well as the global movements organized around culture jamming are grounded in a powerful and broad-based understanding of the convergence of labor and consumption in the world today. These movements understand the links between Nike ads and sweatshops making running shoes, as well as between familiar brands like Wall-Mart, Esprit, Kmart, J. C. Penney, etc. and what can only be described as new forms of slave labor. The links between business and slave labor today are increasingly filling press accounts. In 2002, this was documented in a chilling account of slavery in the mahogany-rich forests and fast food producing cattle ranches of Brazil (Rohter, 2002)..$^{5}$ Global social movements are today based on the ability to strip the cover from the gloss of a brand to reveal not only the exploitation of labor, but also the commercialization of life and threats to the earth's environment. Today's movements range widely and include some whose work is primarily in cyberspace, such as the open source movement, what one analyst calls

\footnotetext{
${ }^{4}$ Coca Cola has actually branded highway signs across Tanzania so that its brand is literally that nation's stop sign.

${ }^{5}$ But there is nothing very new in this account. Back in 1995, the front page of The New York Times featured a report on what amounted to slave labor in the Brazilian rain forest. The twin forces of debt and intimidation fill both articles (Schemo, 1995).
} 
a loose network army of 750,000 software programmers worldwide made up of hackers, crackers, and people running file sharing heirs to Napster like KaZaA. The force is typically far looser than most armies, but it tends to unite against commercialism and the concentration of corporate control over cyberspace (Hunter, 2002). It is also made up of the Centri Sociali movement in Italy that fights to reclaim public space. Their strategies and tactics are not always in line and there is always the threat of co-optation (Himanen, 2001; Wright, 2000; Harmon, 2002). But they are united in providing a genuine alternative to the world that Fukuyama describes as inevitable. In Naomi Klein's blunt words, combining a cultural and political economic understanding, they aim to bring about "the end of The End of History." (Klein, 2001)

As Klein and Dyer-Witheford (1999) describe, many of the major opposition movements have been based on building global political networks through the use of communication systems. This strategy takes many forms including attacks on the communication systems of transnational companies and their political organizations, such as occurred in January 2001 when Microsoft's computer networks and the servers containing private data, such as credit card information, on the elite participants at the World Economic Forum meeting in Davos, Switzerland were hacked and opened (Weisman 2001; Reuters 2001b). It also includes the use of computer communications to organize an alternative to the annual Davos meeting that brought together some 20,000 people in Porto Allegre, Brazil for the World Social Forum, a six day meeting whose theme "Another World is Possible" featured social movement groups representing labor, women, the environment, minorities and numerous other communities.

This potential for a political convergence between labor and consumption demonstrates that convergence does not just mean plugging a cable modem into a PC, or AOL into Time Warner. For some, these global social movements hold out hope for a renewed public sphere, cosmopolitan citizenship and a genuinely democratic cyberspace. The convergence of labor and consumption and the politics of citizenship, which seem to mark so much of what gets all too glibly called the anti-globalization movement, may be the most significant form of convergence to understand today. But there was more such hope before the events of September 11.

The end of history, geography and politics are compelling myths and they are made all the more powerful with the expansion of cyberspace. However, with the spread of anti-globalization movements, and the substantial boost that cyberspace has provided them, even more so with the events of 9/11 and subsequent wars in Afghanistan and Iraq, it appears that time, space and power have returned with a vengeance Indeed, we may be seeing the emergence of a new mythology, or the return of an old one. As John Cassidy put it, "After September 11, it seems ludicrous to speculate about an escape from history or geography.” (Cassidy, 2002: 313) Putting it more powerfully, Robert Kaplan envisions a world ravaged by war, disease and environmental havoc, all of which lay the groundwork for what he calls The Coming Anarchy (1997). 


\section{References}

Associated Press. (2001a), "Internet Naming Group Criticized,” February 14.

Associated Press (2001b), "Nortel Unveils New Technology Tool,” January 30.

Barboza, D. (2002), "Signs of Manipulation in Broadband Trading," The New York Times, May 17, pp. C1, C7.

Barboza, D. and Romero, S. (2002), “Enron is Seen having Link with Global,” The New York Times, May 20, pp. C1, C5.

Barthes, R. (1972 (orig. 1957)) Mythologies, Trans. by A. Lavers. New York: The Noonday Press.

Berman, D. (2002), "Before Telecom Bubble Burst, Some Insiders Sold Out Stakes," The Wall Street Journal, August 12.

Cassidy, J. (2002) Dot. con: The Greatest Story Every Sold, New York: Harper Collins.

Clausing, J. (1999), "Web Domain to Be Assigned For PalestinianTerritory," The New York Times, December 6, p. C-10.

Denning, M. (1996) The Cultural Front, London: verso.

Doniger, W. (1998) The Implied Spider: Politics and Theology in Myth, New York: Columbia University Press.

Dyer-Witheford, N. (1999) Cyber-Marx: Cycles and Circuits of Struggle in High Technology Capitalism, Urbana, Ill. : University of Illinois Press.

Feder, B. J. (2002), “FCC Says Telecom Isn't Doomed by Cutbacks,” The New York Times, online, October 21, (http://www.nytimes.com/2002/10/21/technology/21TELE.html)

Geist, M. (2002a), "Internet Overseer Takes Wrong Path on Accountability,” The Globe and Mail, August 8 , p. B12.

Geist. M. (2002b), "Internet Turf War Playing Out,” The Globe and Mail, November 7, p. B15.

Goodman, P. S. (2002), "Telecom Sector May Find Past is its Future," Washington Post, online (www.washingtonpost.com/wp-dyn/articles/A36589-2002Jul7.html)

“The Great Telecoms Crash,” (2002) The Economist, July 20, p. 9.

Hardt, H. and Brennen B. (eds.) (1995). Newsworkers: Toward a History of the Rank and File, Minneapolis: University of Minnesota Press.

Harmon, A. (2002), "Marketers Try to Turn Web Pirates into Customers," The New York Times, November 4, online (http:// www.nytimes.com/2002/11/04/technology/04TUNE.html.)

Himanen, P. (2001) The Hacker Ethic and the Spirit of the Information Age, New York: Random House.

Howe, P. J. (2002), “Excess Haunts Internet Sector.” The Boston Globe, July 29 (http://www.boston.com/ dailyglobe2/210/business/Excess_haunts_Internet_sector + . shtml)

Hunter, R. (2002) World Without Secrets, New York: Wiley.

Jesdanum, A. (2002), "ICANN's Contrarian Gets the Boot," SiliconValley.com, October 29. (www.siliconvalley.com/mid/siliconvalley/news/editorial/4384835.html)

Kaplan, R. (1997) The Coming Anarchy, New York: Knopf.

Kenny, C. (2003), "Development's False Divide,"

http://www.foreignpolicy.com/issue_janfeb_2003/kenny.html

Klein, N. (2000). No Logo, Toronto: Knopf Canada.

Klein, N. (2001), "A Fete for the End of the End of History," The Nation, March 19.

Krebs, B. (2002), “Bush Stresses Need for Broadband Deregulation.” Washington Post, online, August 14.

Labaton, S. (2002), “Telecom Crisis? Take 2 Aspirin and No One Will Call You in the Morning," The New York Times, July 25: p. C8.

Labaton, S. (2003), "Pentagon Adviser is Also Advising Global Crossing, " The New York Times, March 21, p. C1.

Lewis, M. (2002), “In Defense of the Boom,” The New York Times Magazine, October 27, pp. 44-49, 58-60, 70-72, 84, 94

Longstaff, P. F. (2002) The Communications Toolkit, Cambridge, MA: MIT Press. 
Lyman, R. (1999), "New Digital Cameras Poised To Jolt World of Filmmaking," The New York Times, November 19 , C-1.

Lyon, D. (2001) Surveillance Society, London: Open University Press.

McChesney, R. (1999) Rich Media, Poor Democracy, Urbana, IL: University of Illinois Press.

McKercher, C. (2002) Newsworkers Unite: Labor, Convergence and North American Newspapers, Lanham, Maryland: Rowman and Littlefield.

Miège, B. (1989) The Capitalization of Cultural Production, New York: International General.

Morgenson, G. (2002), “Telecom, Tangled in its Own Web," The New York Times, March 24, Section 3, pp. 1 and 7.

Morgenson, G. (2003), "From WorldCom, An Amazing View of a Bloated Industry," The New York Times, March 16, Section 3, p. 1.

Mosco, V. (2002) "Report on Canada Industrial Relations Board File No. 22076-C re: Application Pursuant to Sections 18, 18. 1 35, 44, 45 \& 46 of the Canada Labour Relations Code between the Telecommunications Workers Union and TELUS Communications Inc.," Submitted to the Canada Industrial Relations Board, June.

Mosco, V. and Schiller, D. (eds.) (2001) Continental Order? Integrating North America for Cybercapitalism, New York: Rowman and Littlefield.

Paré, D. J. (2003) Internet Governance in Transition: Who is the Master of This Domain? Lanham, MD: Rowman and Littlefield.

Pociask, S. (2002) Putting Broadband on High Speed, Washington, D. C. : Economic Policy Institute.

Race, T. (2002), "Scandals Appall Some Longtime Corporate Chiefs," The New York Times, July 1, p. C3.

Reddick, A. (2002) The Dual Digital Divide: The Information Highway in Canada, Ottawa: Public Interest Advocacy Centre.

Reuters. (2001b), “World Economic Forum Says Hackers Got Into System,” The New York Times, online, February

Richtel, M. (2002), “On Its Boards, Silicon Valley Tends to Stand by Its Culture,” The New York Times, July 8, p. C1-2.

Rohatyn, F. (2002a), “The Betrayal of Capitalism,” The New York Review of Books, February 28, p. 6.

Rohatyn F. (2002b), "From New York to Baghdad,” The New York Review of Books, November 21, pp. 4,6 .

Rohter, L. (2002), "Brazil's Prized Exports Rely on Slaves and Scorched Land," The New York Times, March 25, p. A1.

Romero, S. (2002a), "In Another Big Bankruptcy, a Fibre Optic Venture Fails," The New York Times, January 29, pp. A1, C10.

Romero, S. (2002b), "Price is Limiting Demand for Broadband," The New York Times, December 5, p. C5.

Romero, S. and Schiesel, S. (2002), “The Fiber Optic Fantasy Slips Away,” The New York Times, Febuary 17, http:/www.nytimes.com/2002/02/17/business/yourmoney/17BAND.html

Schemo, D. J. (1995), "Brazilians Chained to Job and Desparate," The New York Times, August 10, pp. A1, A6.

Schiesel, S. (2002), “Trying to Catch Worldcom's Mirage,” The New York Times, June 30, pp. 3-1 - 3-14.

Schiller, D. (1999) Digital Capitalism, Cambridge, MA: MIT Press.

Schwartz, J. (2002a), "From Unseemly to Lowbrow, the Web's Real Money is in the Gutter," The New York Times, August 26, pp. C1, C3.

Sidak, J. G. (2002), “The F. C. C. 's Duty,” The New York Times, October 8, p. A31.

Simon, B. (2001), “A Telecom Umbrella Extends its Shadow,” The New York Times, December 24, p. C3.

Sunstein, C. (2001) Republic.com., Princeton, N. J. : Princeton University Press.

Sussman, G. and Lent, J. (eds.) (1998) Global Productions, London: Sage.

Tedeschi, B. (2002), "EBay is the Internet's Retailing Success Story. So Why are Some People Making Cautionary Noises?" The New York Times, November 25, p. C8. 
Thompson, B. (2002), "Why the Poor Need Technology," BBC News World Edition. October 6 (http: //news. bbc. co. uk/2/hi/technology/2295447. stm).

U. S.government, Department of Commerce, Office of Technology Policy (2002). On the Net. Washington, D. C. : Department of Commerce. (http://www.ta.doc.gov/OTPolicy/default.html).

van Ham, P. (2001), "The Rise of the Brand State:The Postmodern Politics of Image and Reputation," Foreign Affairs (September/October), (Online) http://www.foreignaffairs.org/articles/VanHam0901.html.

Weed, W. S. (2002), "Phony Science: Questions for Paul Ginsparg," The Sunday Times Magazine, October 13, p. 27.

Weinstein, L. (2002), "ICANN Needs Another Long Trip," Wired, online, November 18 (http:// www.wired.com/news/politics/0,1283,56398,00.html).

Weisman, R. (2001), “DoS Attacks: Internet Plague Without a Cure?” NewsFactor Network, January 31, (http://www.newsfactor.com/perl/story/7050.html).

Weiss, T. R. (2001), “ICANN, Under Fire, Targets Alternate Top-level Domain Name System,” Computerworld, May 31, http://www.computerworld.com/cwi/stories/0,1199,NAV47_STO60980,00.html.

Wright, S. (2000), “'A Love Born of Hate': Autonomist Rap in Italy,” Theory, Culture, and Society, Vol. 17, n. ${ }^{\circ} 3$, pp. 117-135. 